\title{
Creatine Kinase Release, Potassium-42 Content, and Mechanical Performance in Anoxic Rabbit Myocardium
}

\author{
Gary L. Conrad, Eric E. Rau, and Kenneth I. Shine, Departments of Medicine \\ and Physiology, and the American Heart Association, Greater Los Angeles \\ Affiliate Cardiovascular Research Laboratory, University of California at \\ Los Angeles, Center for the Health Sciences, Los Angeles, California 90024
}

A B S T RACT We studied whether creatine kinase appearance in venous effluent was specific for, and quantitatively proportional to, the amount of loss of functioning myocardium. Cell viability was determined by simultaneously monitoring tissue ${ }^{42} \mathrm{~K}$ content and mechanical performance during anoxia and reoxygenation in isolated, arterially perfused, interventricular rabbit septa. The septa were paced at 42 beats $/ \mathrm{min}$ and perfused at $1.8 \mathrm{ml} / \mathrm{min}$ per $\mathrm{g}$ tissue with a modified Tyrode solution at $28^{\circ} \mathrm{C}$. Net total creatine kinase losses of $5.3 \pm 2.7,20.6 \pm 7.2,55.3 \pm 7.6$, and $110.7 \pm 27.1$ IU/g dry wt (mean \pm SEM) were observed after 20,30 , 40 , and 60 min of anoxia, respectively. Maximum ${ }^{42} \mathrm{~K}$ losses during the same intervals of anoxia were 16.8 $\pm 3.4,38.3 \pm 2.9,47.0 \pm 1.4$, and $84.3 \pm 14.8 \mathrm{mmol} \mathrm{K}+/ \mathrm{kg}$ dry wt and correlated with creatine kinase losses, $r=0.97$. Upon reoxygenation, ${ }^{42} \mathrm{~K}$ content returned to a new plateau which was expressed as a percentage of decrease from control content. These unrecovered ${ }^{42} \mathrm{~K}$ losses were $-2.7 \pm 0.9,0.7 \pm 2.9,6.6 \pm 1.9$, and 14.0 $\pm 6.5 \%$ after $20,30,40$, and 60 min of anoxia, respectively, and correlated with the creatine kinase loss, $r=0.97$. Net loss of developed tension after reoxygenation was $9.0 \pm 2.3,26.7 \pm 17.9,31.7 \pm 1.1$, and $60.7 \pm 8.8 \%$ of control after these anoxic intervals and correlated with creatine kinase loss, $r=0.92$. The small enzyme loss that occurred after $20 \mathrm{~min}$ anoxia without evidence for irreversible loss of cell function was $\cong 0.1 \%$ of total tissue enzyme content. The significant correlation of enzyme loss with the irreversible losses of potassium content and contractile performance supported the hypothesis that creatine kinase appearance in the venous effluent was the result of cell death.

Address reprint requests to Dr. Conrad at Harvey 402, The Johns Hopkins Hospital, Baltimore, Md. 21205.

Received for publication 28 August 1978 and in revised form 26 February 1979.

\section{INTRODUCTION}

Creatine kinase $(\mathrm{CK})^{1}$ is used as an enzyme marker for the identification and quantification of irreversible loss of cell function and myocardial necrosis $(1,2)$. This approach is based primarily upon studies correlating CK losses with histological estimates of myocardial necrosis $(1,3,4)$. Yet the specificity of CK appearance for myocardial cell necrosis has been questioned and studies in humans and animals have suggested CK release in the absence of overt myocardial cell injury and without proportionality to the extent of identified injury (5-7). The isolated, arterially perfused, interventricular rabbit septum provides a model for studying $\mathrm{CK}$ appearance in the effluent while monitoring other parameters of cellular viability including cellular ${ }^{42} \mathrm{~K}$ content and mechanical function. Because $98 \%$ of myocardial potassium is intracellular (8), tissue ${ }^{42} \mathrm{~K}$ activity is an excellent real time marker of cellular integrity and viability to follow during stresses. Previous data from this laboratory have characterized the mechanical events and changes in potassium content during anoxia in this model (9). In this study we will demonstrate the $\mathrm{CK}$ appearance in the effluent is proportional to the amount of irreversible ${ }^{42} \mathrm{~K}$ loss and the degree of injury to mechanical performance after anoxic stresses in rabbit myocardium.

\section{METHODS}

Experimental preparations. The experimental preparations were isolated, arterially perfused, interventricular septa of $1.5-2.0-\mathrm{kg}$ male New Zealand white rabbits, according to the techniques described by Rau et al. (9). After heparinization (10,000 U U. S. Pharmacopeia i.v.) and anesthesia (180 mg pentobarbital i.v.) the hearts were rapidly removed, the septal artery branch of the left coronary artery was cannulated with a polyethylene cannula, and the septa were perfused

\footnotetext{
${ }^{1}$ Abbreviation used in this paper: CK, creatine kinase.
} 
at a constant flow by a Harvard pump (Harvard Apparatus Co., Inc., Millis, Mass.). A triangular piece of well-perfused septum $(0.8-1.1 \mathrm{~g}$ wet wt) was dissected and a silk suture used to suspend the apex from a Statham UC4 transducer (Statham Instruments, Inc., Oxnard, Calif.) for tension monitoring. The base of the tissue was secured by two opposing forceps. The transducer recorded only that vector of tension developed along the axis of the transducer. The proportion of total force represented by this vector remained constant throughout each experiment. Resting tension was maintained at $5 \mathrm{~g}$, with septa being accepted for study if they developed a minimum of $15 \mathrm{~g}$ tension, $100 \mathrm{~g} / \mathrm{s}$ positive $d T / d t$. Perfusate temperature was maintained at $28^{\circ} \mathrm{C}$ by passing current through a $200-\mathrm{ohm}$ power resistor placed around the metal perfusion cannula which was attached to the polyethylene cannula. Electrodes from a Grass Stimulator (model SD9, Grass Instrument Co., Qunicy, Mass.) attached to the harmon forceps paced the septa at 42 beats $/ \mathrm{min}$. The tissues were perfused at $1.8 \mathrm{~cm}^{3} / \mathrm{min}$ per $g$ wet wt with a modified Tyrode solution containing (in millimolars): $\mathrm{NaCl}$, 130; $\mathrm{NaHCO}_{3}, 12: \mathrm{MgCl}_{2}, 1.0 ; \mathrm{KCl}, 5.0 ; \mathrm{CaCl}_{2}, 1.5 ; \mathrm{NaH}_{2} \mathrm{PO}_{4}$, 0.435 ; dextrose, 5.6 or 20 . Solutions were equilibrated with $98 \% \mathrm{O}_{2} / 2 \% \mathrm{CO}_{2}$ or for anoxia, $98 \% \mathrm{~N}_{2}$ and $2 \% \mathrm{CO}_{2}$. Under these conditions, the tissues reached a steady state for mechanical performance, $\mathrm{CK}$ release, and ionic and water content, after a gain of water and a loss of potassium over the initial $60-180 \mathrm{~min}$ of perfusion (9). ${ }^{42} \mathrm{~K}$ (as $\mathrm{KCl}$, New England Nuclear, Boston, Mass.) was added to perfusate to maintain the final concentration at $5 \mathrm{mM}$ potassium. The ${ }^{42} \mathrm{~K}$ activity of the entire muscle was continuously monitored on-line by a NaI crystal (Nuclear Enterprises, Inc., San Carlos, Calif.). Details of the isotopic procedure are reported elsewhere (9). The septa remained stable for 5-7 h, which allowed for full evaluations of anoxic stresses. It was thus possible to continuously and simultaneously monitor mechanical performance parameters and potassium content while collecting effluent below the septum for enzyme analysis.

Analytical procedures. $1-\mathrm{cm}^{3}$ samples of effluent for CK analysis were collected and stored in $0.01 \mathrm{M}$ mercaptoethanol, $0.01 \mathrm{M}$ EGTA, at $4^{\circ} \mathrm{C}$. All samples were analyzed 3-7 d after each experiment, to allow the ${ }^{42} \mathrm{~K}$ to decay, over which time CK was verified to be $95 \%$ stable (10). The amount of CK appearing in the effluent was quantified by integrating the area within effluent curve minus the extrapolated steady-state CK appearance. At the onset of anoxia a decrease in the CK appearing in the effluent was usually observed (Fig. 3). This amount of CK which did not appear in the effluent during the first minutes of anoxia was quantitated and subtracted from the CK loss that occurred during the periods of anoxic stress and recovery. This correction decreased the calculated CK loss that occurred. The necessity for making this subtraction is evidenced in Fig. 1. During quiescence, a transient fall in the level of CK appearing in the effluent was observed. Upon restimulating the septum at $42 / \mathrm{min}$, a transient increase in CK levels appeared, probably because of a direct effect of increased mechanical squeezing. Presumably, this same mechanism operated at the onset of anoxia, as developed tension quickly fell, and at reoxygenation as developed tension increased (Figs. 3 and 4).

By using the modified Rosalki procedure, samples were analyzed via coupled enzyme reactions monitoring linear $\mathrm{NADH}$ production at $340 \mathrm{~nm}, 30^{\circ} \mathrm{C}$, in a Gilford spectrophotometer (Gilford Instruments Laboratories Inc., Oberlin, Ohio). Assay packs were obtained from Calbiochem (Calbiochem-Behring Corp., American Hoechst Corp., San Diego, Calif.) and CK standards from Hyland (Hyland Diagnostics Div., Travenol Laboratories, Inc., Costa Mesa, Calif.). Effluent samples were diluted in a solution containing $0.2 \%$ bovine serum albumin and $0.02 \mathrm{M}$ Tris to keep the final CK concentrations between 10 and 300 IU/liter. Effluent samples plus reaction mixture showed no NADH production in the absence of creatine phosphate. Total tissue CK content was analyzed by a method modified from Roberts et al. (11). After being weighed and minced, the tissues were homogenized in a solution containing $0.25 \mathrm{M}$ sucrose, $0.01 \mathrm{M}$ Tris, 0.001 M EGTA, 0.01 mercaptoethanol, $\mathrm{pH} 7.4$, for three 10-s bursts of a Polytron (model PCU-2-110 generator No. PT 10ST, Brinkmann Instruments, Inc., Westbury, N. Y.). After centrifugation at $2,000 \mathrm{~g}$ for $10 \mathrm{~min}$, the supernates were retained and the pellets were rewashed. More than $75 \%$ of the total recoverable CK consistently appeared in the first supernate, $20 \%$ in the second, and $<5 \%$ in subsequent washes with this method. CK activity in the first and second washes was subsequently added together as total activity.

Experimental procedure. A 150-min equilibration period elapsed before any experimental intervention. When ${ }^{42} \mathrm{~K}$ counts in the tissue approached asymptotic levels and mechanical performance was stable, anoxia was induced by switching to identical solution equilibrated with $\mathrm{N}_{2} / \mathrm{CO}_{2}$. After the anoxic stress, ${ }^{42} \mathrm{~K}$ counts and tension were monitored for at least $90 \mathrm{~min}$ while collecting effluent samples below the septum at regular intervals for $\mathrm{CK}$ analysis. At the end of each experiment the tissue was blotted and dried for $24 \mathrm{~h}$ at $110^{\circ} \mathrm{C}$. The tissue was reweighed to obtain the dry weight, then dissolved in acid and counted for ${ }^{42} \mathrm{~K}$ content determinations (9).

Statistics. Regression coefficients were determined by the method of least squares. Correlation coefficients were calculated by standard techniques and used to estimate the proportion of the variance of one variable that could be attributed to its linear regression on the second.

\section{RESULTS}

CK loss in the absence of anoxia. As previously reported (9), the ${ }^{42} \mathrm{~K}$ counts in the perfused septum reached an asymptotic value within 150-180 min (Fig. 1). The ${ }^{42} \mathrm{~K}$ counts, corrected for decay, and mechanical parameters remained stable for $5-7 \mathrm{~h}$. After $3 \mathrm{~h}$ of perfusion the CK content of the effluent from septa had plateaued at $0.4-0.8 \mathrm{IU} / \mathrm{min}$ per g dry wt, or $<0.01 \%$ / min of the total septal CK. This low level of CK appearance corresponds with physiologic levels and further proves the stability of the preparation. In one experiment the stimulator was turned off at $264 \mathrm{~min}$ (Fig. 1). A decline in appearance of CK was observed. At 274 min the stimulation was resumed. CK content of the effluent increased abruptly, returning to the prequiescent levels after 6 min.

CK loss during anoxia. Fig. 2 demonstrates the typical responses to $20 \mathrm{~min}$ of anoxia. At $170 \mathrm{~min}$ the muscle was perfused with anoxic solution. Tension and ${ }^{42} \mathrm{~K}$ activity immediately declined. Reoxygenation at $190 \mathrm{~min}$ resulted in recovery of tension and ${ }^{42} \mathrm{~K}$ content to new stable levels. The ${ }^{42} \mathrm{~K}$ counts always recovered to a level $>100 \%$ of control during recovery from $20 \mathrm{~min}$ of anoxia. In the 20-min anoxic studies CK appeared in the effluent only after reoxygenation. In the experiment illustrated by Fig. 2, the CK loss was calculated to be $5 \mathrm{IU} / g$ dry wt. 


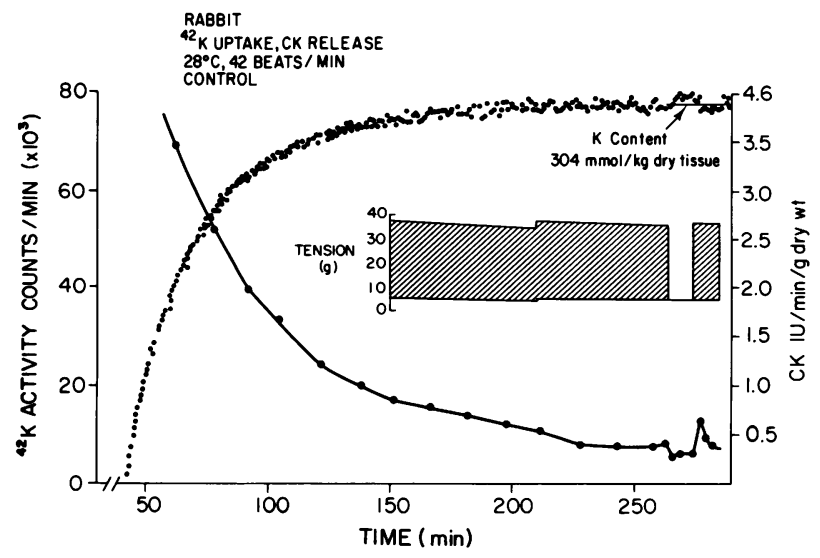

FIGURE 1 CK effluent appearance, ${ }^{42} \mathrm{~K}$ counts, and tension for a septum with no anoxic intervention. Dots represent ${ }^{42} \mathrm{~K}$ content (left ordinate) which increased after loading began at $40 \mathrm{~min}$ and plateaued at $180 \mathrm{~min}$. Solid line of effluent CK activity (right ordinate) fell rapidly and began to level off at $230 \mathrm{~min}$. The tension fell slowly as the resting tension decreased and was restretched at $210 \mathrm{~min}$ to maintain a resting tension of $5 \mathrm{~g}$. Stimulator was turned off from 264 to 274 min resulting in a fall and then a brief peak in enzyme appearance.

Fig. 3 demonstrates changes seen during and after $30 \mathrm{~min}$ of anoxia. In addition to the fall in developed tension during anoxia, the resting tension increased and did not return to preanoxia levels after reoxygenation. The septum lost $34 \mathrm{mmol} \mathrm{K} / \mathrm{kg}$ dry wt during anoxia and returned to a new plateau level after reoxy-

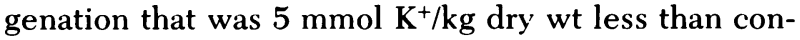
trol. This potassium loss was termed unrecovered potassium. The rate of CK appearance in the effluent declined during anoxia, increased upon reoxygenation, and achieved its peak level $20 \mathrm{~min}$ after reoxygenation.

The effects of $40 \mathrm{~min}$ of anoxia are seen in Fig. 4.

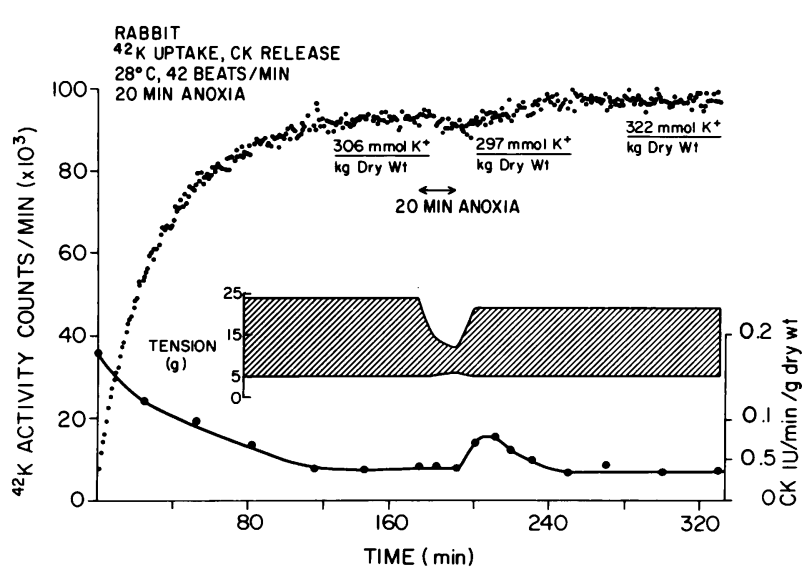

Figure $2{ }^{42} \mathrm{~K}$ counts, (dots), CK release (solid line), and tension with $20 \mathrm{~min}$ of anoxia. There was a small fall in ${ }^{42} \mathrm{~K}$ counts during anoxia with the characteristic rise to a higher plateau after reoxygenation.

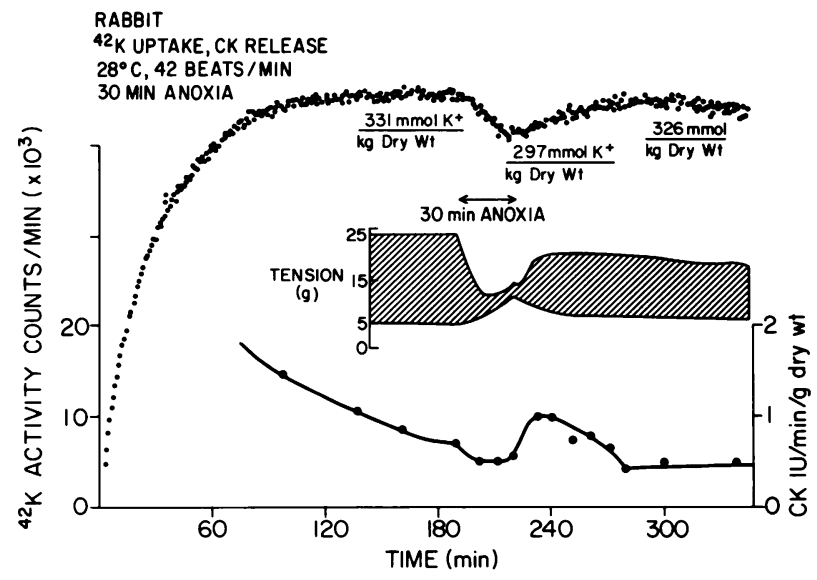

Figure $3{ }^{42} \mathrm{~K}$ counts, CK appearance (solid line), and tension with 30 min of anoxia. Resting tension rose during anoxia with incomplete return to preanoxia levels after reoxygenation. Note that CK appearance decreased initially during the anoxia stress as developed tension fell.

Spontaneous premature contractions occurred at $160-170 \mathrm{~min}$ and resulted in a loss of developed tension. Anoxia was initiated at $210 \mathrm{~min}$. After $40 \mathrm{~min}$ a significant rise in resting tension was observed. Upon reoxygenation developed tension recovered to a new level for a net loss of $39 \%$ from the preanoxia level. Potassium content declined from $244 \mathrm{mmol} \mathrm{K}^{+} / \mathrm{kg}$ dry wt before anoxia to a postreoxygenation level of 235 $\mathrm{mmol} \mathrm{K}+\mathrm{kg}$ dry wt, representing an unrecovered loss of $4 \%$ of the control content. The rate of CK appearance in the effluent began to increase before reoxygenation in this and all anoxic stresses longer than $30 \mathrm{~min}$. The CK appearance rate was accelerated by reoxygenation and the peak level occurred $20 \mathrm{~min}$ later. The rate of

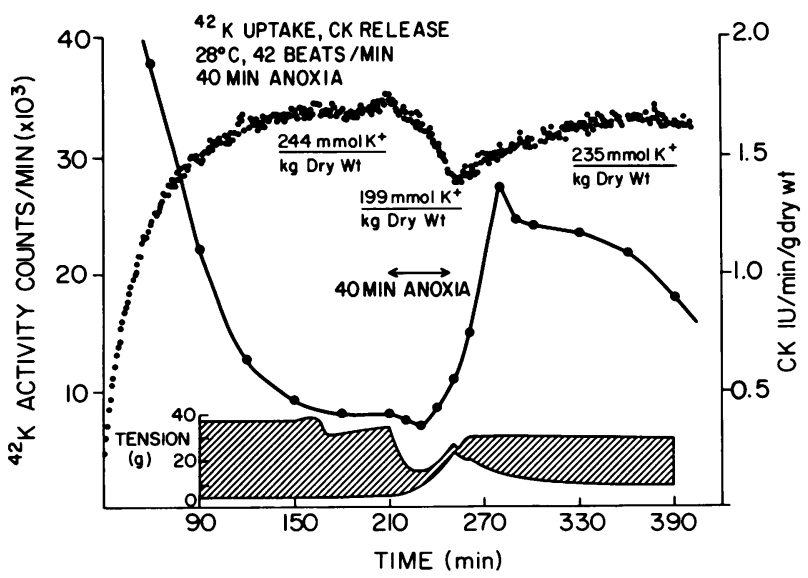

Figure $4{ }^{42} \mathrm{~K}$ counts, CK appearance (solid line), and tension with $40 \mathrm{~min}$ of anoxia. Fall in tension at $165 \mathrm{~min}$ resulted from spontaneous ectopy. Note that CK appearance initially decreased during anoxia then began increasing at $30 \mathrm{~min}$, before reoxygenation. 
TABLE I

CK Appearance and Cellular Parameters during and after Anoxia

\begin{tabular}{|c|c|c|c|c|c|c|}
\hline $\begin{array}{c}\text { Period of } \\
\text { anoxia }\end{array}$ & & CK loss & $\begin{array}{c}{ }^{42} \mathrm{~K} \text { loss } \\
\text { during anoxia }\end{array}$ & $\begin{array}{c}\text { Net }{ }^{42} \mathrm{~K} \text { loss } \\
\text { after reoxygenation }\end{array}$ & $\begin{array}{c}\text { Net DT loss } \\
\text { after reoxygenation }\end{array}$ & $\begin{array}{c}\text { Maximum rise } \\
\text { RT during anoxia }\end{array}$ \\
\hline $\min$ & $n$ & $I U / g d r y w t$ & $K^{+} / k g d r y u t$ & \multicolumn{2}{|c|}{$\%$ control } & $g$ \\
\hline 20 & 6 & $5.3 \pm 2.7$ & $16.8 \pm 3.4$ & $-2.7 \pm 0.9$ & $9.0 \pm 2.3$ & $1.4 \pm 0.4$ \\
\hline 30 & 3 & $20.6 \pm 7.6$ & $38.3 \pm 2.9$ & $0.7 \pm 2.9$ & $26.7 \pm 17.9$ & $6.3 \pm 3.9$ \\
\hline 40 & 3 & $55.3 \pm 7.6$ & $47.0 \pm 1.4$ & $6.6 \pm 1.9$ & $31.7 \pm 1.1$ & $11.0 \pm 4.9$ \\
\hline 60 & 4 & $110.7 \pm 27.1$ & $84.3 \pm 14.8$ & $14.0 \pm 6.5$ & $60.7 \pm 8.8$ & $17.5 \pm 2.6$ \\
\hline
\end{tabular}

All values are mean \pm SEM. DT, developed tension; $R T$, resting tension.

CK appearance did not always return to control rates during reoxygenation after $30 \mathrm{~min}$ of anoxia. In these cases the effluent curve was extrapolated to control rates. The area under the extrapolated portion of the curve never exceeded $5 \%$ of the observed CK effluent losses.

A summary of these data is presented in Table I. With longer periods of anoxia a greater CK loss occurred. This was associated with greater potassium losses during anoxia and greater unrecovered potassium losses after reoxygenation. Similarly, longer periods of anoxia resulted in a greater rise in resting tension during anoxia and a greater net loss of developed tension after reoxygenation. The small $(5 \mathrm{IU} / \mathrm{g}$ dry tissue) enzyme loss that occurred after $20 \mathrm{~min}$ of anoxia was $\cong 0.1 \%$ of the total tissue enzyme content. The correlation of total CK appearance with these variables was demonstrated in Figs. 5-8. CK loss correlated with ${ }^{42} \mathrm{~K}$ loss during anoxia with an $r$ value of 0.97 (Fig. 5). The abscissa intercept of $19 \mathrm{mmol}$ $\mathrm{K}^{+} / \mathrm{kg}$ dry wt reflected the minimum level of potas-

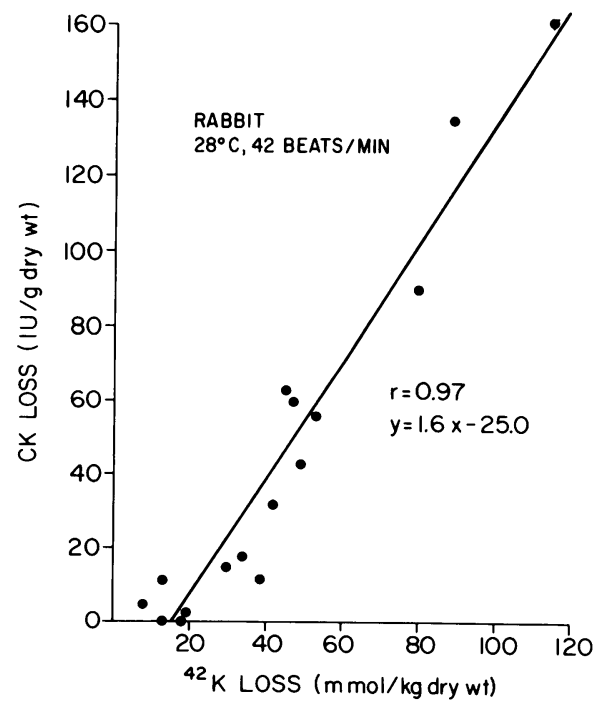

Figure 5 Total CK loss vs. ${ }^{42} \mathrm{~K}$ loss during anoxia. sium loss during anoxia which was associated with no increase in CK appearance, and $>100 \%{ }^{42} \mathrm{~K}$ recovery after reoxygenation. CK loss correlated with unrecovered ${ }^{42} \mathrm{~K}$ net loss $(r=0.96$ ). The negative net (or unrecovered) (Fig. 6) losses reflected the $>100 \%{ }^{42} \mathrm{~K}$ recovery seen after $20 \mathrm{~min}$ of anoxia. The postrecovery net loss in developed tension (DT), expressed as a percentage of preanoxia DT, correlated with CK loss, $r=0.92$ (Fig. 7). Finally, the rise in resting tension which occurred during anoxia was also significantly correlated with the CK loss $r=0.89$ (Fig. 8). No significant differences were observed between responses of muscles perfused with 5 or $20 \mathrm{mM}$ dextrose.

Total CK content. Three septa were analyzed for total CK content after $5 \mathrm{~h}$ of perfusion with no experimental intervention. CK recovered was $6,670 \pm 980 \mathrm{IU} /$ g dry wt or $970 \pm 90 \mathrm{IU} / \mathrm{g}$ wet wt, mean \pm SEM. The septal wet weight after an experiment ranged from 0.8 to $1.0 \mathrm{~g}$ and the total septal CK content was at least $800-1,000 \mathrm{IU}$. The seven experiments that obtained $100 \%$ or greater recovery of potassium content and $90 \%$ or greater recovery of DT lost an average of 6 IU $\mathrm{CK} / \mathrm{g}$ dry wt. Two muscles obtained $100 \%$ mechanical recovery, both after $20 \mathrm{~min}$ of anoxia. One of these septa showed no increased CK appearance and the other had

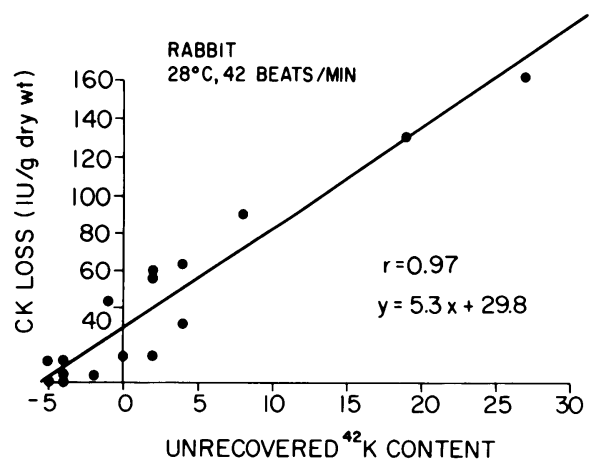

Figure 6 Total CK loss vs. net loss of ${ }^{42} \mathrm{~K}$ after reoxygenation. Negative values represent contents greater than control with reoxygenation after short periods of anoxia (text for discussion). 


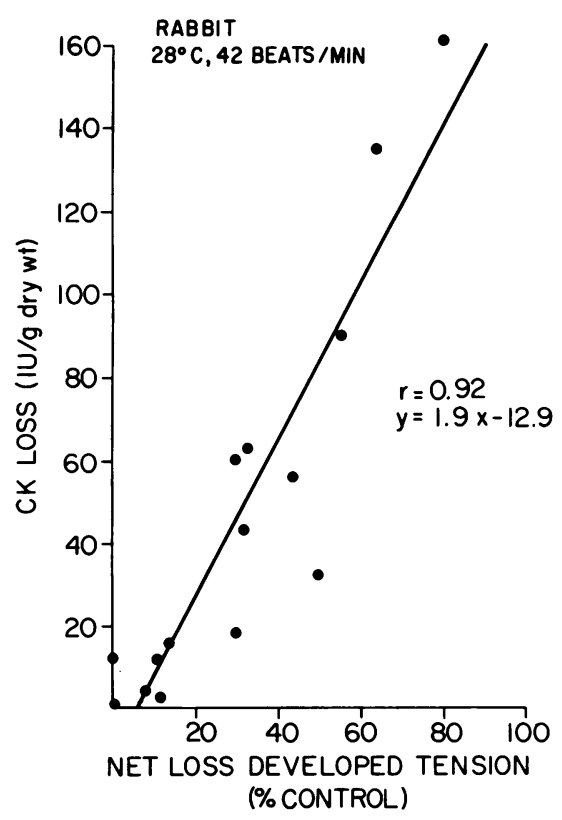

Figure 7 Total CK loss vs. net loss of developed tension after recovery.

a total of CK appearance of $12 \mathrm{IU} / \mathrm{g}$ dry wt, $\cong 0.2 \%$ of the average total CK content.

\section{DISCUSSION}

The appearance of CK in serum is used as a biochemical marker for the identification and quantification of myocardial necrosis $(1,2)$. However conflicting evidence exists in the literature concerning the interpretation of elevated CK levels. Evidence supporting

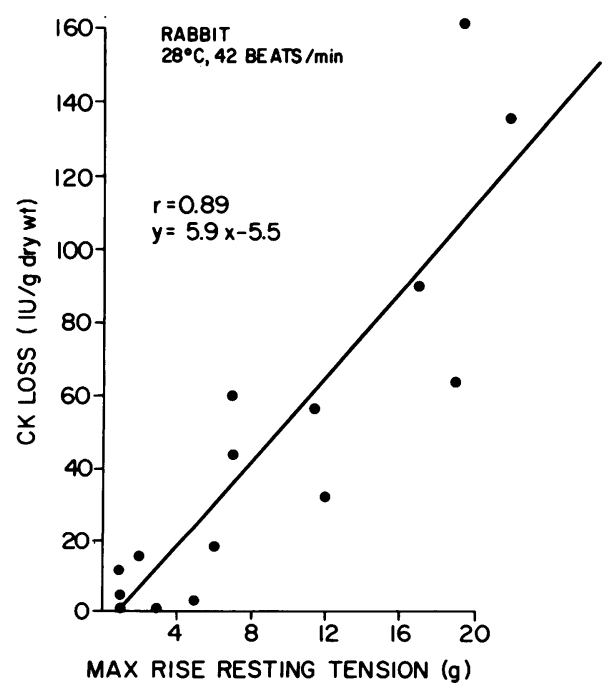

FIgURE 8 Total CK loss vs. maximum rise in resting tension during anoxia. the use of serum CK levels as an index of cell death rests largely on data from canine experiments and perfused whole heart experiments and suggests that membrane disruption associated with cell death allows the appearance of CK in serum. Hearse and Humphrey (12) used nonbeating, anoxic whole heart preparations from several species to study CK release and showed close correlations between CK appearance, the falls in ATP and creatine phosphate levels, and disruption of cellular ultrastructure. Using a canine preparation Ahmed et al. (3) evaluated serum CK and histological changes after ischemia and found that large CK appearances were highly correlated with histochemically proven cell death. Evidence against the use of CK appearances as a marker of cell death argue that small increases in serum enzyme levels could be related to the state of cellular energy levels or cellular membrane integrity, and not to cell death and disruption of the cellular membrane (13). Small rises in serum CK levels have been observed with no histochemical evidence of cell death in ischemic dog hearts (3) or loss of mechanical performance in ischemic guinea pig hearts (7). Similarly, Klein et al. (6) observed increases in serum levels of the MB isoenzyme of $\mathrm{CK}$ after cardiovascular surgery when electrocardiogram and radionucleotide scans failed to detect myocardial cell necrosis.

Similar conflicting information exists concerning the use of elevated serum CK levels as an index of the size or amount of cell necrosis. Shell et al. (1) found that total CK appearance in the serum was proportional to the amount of CK depletion in the area of experimental infarction, and Kjekshus and Sobel (4) showed that CK losses correlated with histologically determined sizes of infarction. Contraindicating the use of serum CK levels as an index of the amount of cell necrosis are the results of studies by Jarmakani et al. (5) and Maroko and Vatner (14), which showed a large effect of reperfusion on the amount of CK released and would therefore allow prediction of infarct size from CK data only if the reperfusion effect was known and quantified. Despite these discrepancies, the amount of CK appearing after a myocardial infarction or intervention is being used as a measure of the amount of cell necrosis (15). Use of an isolated, controlled, experimental preparation allowed us to directly and simultaneously evaluate CK release, cellular viability as measured by the ability to maintain or recover a potassium gradient, and mechanical performance in the heart.

We used the isolated, arterially perfused, beating, intraventricular rabbit septum as the preparation for these studies. This preparation allowed complete control of the entire tissue being stressed by anoxia including control of: temperature, beating rate, end diastolic tension (rest tension), perfusate content, and rate of perfusion, and permitted simultaneous, 
real time monitoring of contractile performance, tissue potassium content $\left({ }^{42} \mathrm{~K}\right)$, and appearance of $\mathrm{CK}$ in the effluent. Because $98 \%$ of tissue ${ }^{42} \mathrm{~K}$ is intracellular (8), monitoring tissue counts was a sensitive index of cellular ${ }^{42} \mathrm{~K}$ content and therefore of the cellular sarcolemmal membrane integrity and performance (9). Postanoxic recovery of tissue ${ }^{42} \mathrm{~K}$ counts served as an indication of cell viability as it has previously been shown that irreversibly injured cells do not recover their potassium content while reversibly injured ones can (16). CK appearance in the effluent was substantial for 150 min after cannulation of the isolated septum (Fig. 1). This initial CK appearance averaged $80 \mathrm{IU}$ and represented losses up to $13 \%$ of the total tissue CK content. These losses apparently resulted from injury to cells during dissection and cannulation. Thereafter CK loss diminished to a level $<0.01 \% / \mathrm{min}$ of total tissue CK and the septa remained mechanically stable, and maintained their ${ }^{42} \mathrm{~K}$ content for 5-7 h. During this stable period we followed enzyme appearance, ${ }^{42} \mathrm{~K}$ counts, and tension during anoxia and after reoxygenation.

Our results showed a significant correlation between CK appearance and the loss of potassium and tension after anoxic stress. Mean changes of mechanical function, CK appearance in the effluent, and ${ }^{42} \mathrm{~K}$ content after four different time periods of anoxia were summarized in Table I. CK appearance always fell during anoxia as the developed tension decreased. Upon reoxygenation the effluent enzyme concentration increased and peaked at $20 \mathrm{~min}$. With longer periods of anoxia CK appearance began to increase at $30 \mathrm{~min}$ but further increased upon reoxygenation. This acceleration in rate of appearance upon reoxygenation could have resulted from a mechanical squeeze as the developed tension increased (17), in addition to the direct cellular effects of oxygen described in the studies of Hearse and Humphrey (12). Potassium losses during anoxia have been shown to be due to increased efflux of ions from cells despite the presence of high energy phosphate levels sufficient to maintain the Na-K pump (9). The potassium lost during the period of anoxia was highly correlated with the CK appearance in the effluent (Fig. 5). The recovery of potassium content was a direct measurement of cellular viability because irreversibly injured cells cannot regain their potassium content. Recovery of potassium content to levels slightly higher than control values after $20 \mathrm{~min}$ of anoxia has been previously observed and was due to a diminished efflux of potassium after reoxygenation (9). This observation explains the ordinate intercept seen in Fig. 6. With longer periods of anoxia the potassium content did not return to preanoxia levels after reoxygenation. During recovery after $60 \mathrm{~min}$ anoxia, four septa recovered an average of $86 \%$ of the control potassium content, representing a net loss of $14 \%$. This evidence for loss of cellular viability was associated with a proportional increase in CK effluent appearance (Fig. 6). The mean CK losses after the $60 \mathrm{~min}$ of anoxia was $\cong 2 \%$ of the total septal CK content, or one-seventh of the observed net potassium loss. A similar proportionality of 1:7 has been observed in experimental models using CK depletion from infarcted myocardium, where only one-seventh of the depleted CK is accounted for in the serum (2). This disappearance of enzyme was presumed to be due to degradation or inactivation and could explain the discrepancy we observed between the total CK losses and potassium losses after the various periods of anoxia. The significant correlation between unrecovered potassium content and CK appearance was direct evidence for the appearance of the enzyme correlating with the amount of loss of nonfunctioning myocardium.

Mechanical parameters have previously been used to follow cellular viability and function (9). Loss of developed tension, after anoxia, although not as a direct a measurement of irreversible cell damage as potassium loss, correlated well with total CK loss. Resting tension rises during anoxia, because irreversibly damaged myocardium goes into contracture. This parameter was also proportional and well correlated with the total CK loss.

Seven septa obtained $100 \%$ or greater recovery of potassium and $90 \%$ or greater recovery of developed tension. Concerning the question of specificity of CK appearance for cell necrosis, a small increase in CK appearance occurred in several of these septa, averaging $6 \pm 3 \mathrm{IU} / \mathrm{g}$ dry wt, or $0.1 \%$ of the total tissue levels of CK. After correcting for the estimated 1:7 proportionality of CK appearance:CK loss, the quantity of enzyme lost by these tissues obtaining 90-100\% recovery was $<1 \%$ of the total CK content of the tissue. This small loss may possibly have reflected the greater sensitivity of the effluent enzyme appearance for a very small quantity of cellular necrosis. We could not differentiate a loss of CK due to irreversible damage to a $1 \%$ fraction of less well perfused cells from a small CK "leak" from viable cells with $100 \%$ recovery, but the contribution of such a leak would have been $<1 \%$.

This experimental model, involving a stable beating ventricular septum with physiologic perfusion rates, allows several further observations on $\mathrm{CK}$ release. Our studies confirmed the importance of contractile function, probably occurring through increased mechanical squeezing, influencing enzyme appearance in the effluent perfusate. This has been previously described for lactate dehydrogenase (17). Also, previous studies of CK release during graded hypoxia may be influenced not only by mechanical effects but also by the striking inhomogeneity of the hypoxic insult which may actually be anoxic in some areas with adequate oxygenation in others (18). The degree of mechanical im- 
pairment and the rate of recovery of contractile function during or after tissue injury significantly influenced the time course of appearance of the enzyme.

Using the postanoxic recovery of ${ }^{42} \mathrm{~K}$ content as a marker of cellular viability while measuring mechanical performance and CK losses, we obtained a significant correlation between the net total CK loss and both the loss of ${ }^{42} \mathrm{~K}$ content and loss of contractile performance. The amount of CK that appeared in the venous effluent, in several experiments in the absence of loss of cell function, was a very small percentage of the total tissue content of CK. CK appeared to be a quantitative marker for cell death.

\section{ACKNOWLEDGMENTS}

The research for this paper was supported by grant HL 11351-11 from the U. S. Public Health Service and grant 570 from the American Heart Association, Greater Los Angeles Affiliate.

\section{REFERENCES}

1. Shell, W. E., J. K. Kjekshus, and B. E. Sobel. 1971. Quantitative assessment of the extent of myocardial infarction in the conscious dog by means of analysis of serial changes in serum creatine phosphokinase activity. J. Clin. Invest. 50: 2614-2625.

2. Sobel, B. E., R. Roberts, and K. B. Larson. 1976. Considerations in the use of biochemical markers of ischemic injury. Circ. Res. 38: I-99-I-108.

3. Ahmed, S. A., J. R. Williamson, R. Roberts, R. E. Clark, and B. E. Sobel. 1976. The association of increased plasma MB CPK activity and irreversible ischemic myocardial injury in the dog. Circulation. 54: 187-193.

4. Kjekshus, J. K., and B. E. Sobel, 1970. Depressed myocardial creatine phosphokinase activity following experimental myocardial infarction in rabbit. Circ. Res. 27: 403-414.

5. Jarmakani, J. M., L. Limbird, T. C. Graham, and R. A. Marks. 1976. Effect of reperfusion on myocardial infarct, and the accuracy of estimating infarct size from serum creatine phosphokinase in the dog. Cardiovasc. Res. 10: 245-253.

6. Klein, M. S., R. E. Coleman, C. S. Weldon, B. E. Sobel, and R. Roberts. 1976. Concordance of electrocardiographic and scintigraphic criteria of myocardial injury after cardiac surgery. J. Thorac. Cardiovasc. Surg. 71: 934937.

7. Sakai, K., M. M. Gebhard, P. G. Spieckermann, and J. H. Bretschneider. 1975. Enzyme release resulting from total ischemia and reperfusion in the isolated, perfused guinea pig heart. J. Mol. Cell. Cardiol. 7: 827-840.

8. Blesa, E. S., G. A. Langer, A. J. Brady, and S. D. Serena. 1970. Potassium exchange in rat ventricular myocardium: its relation to rate of stimulation. Am. J. Physiol. 219: 747-754.

9. Rau, E. E., K. I. Shine, and G. A. Langer. 1977. Potassium exchange and mechanical performance in anoxic mammalian myocardium. Am. J. Physiol. 232(1): H85H94.

10. Morin, L. G. 1977. Creatine kinase: stability, inactivation, reactivation. Clin. Chem. 23: 646-652.

11. Roberts, R., K. S. Gowda, P. A. Ludbrook, and B. E. Sobel. 1975. Specificity of elevated serum MB creatine phosphokinase activity in the diagnosis of acute myocardial infarction. Am. J. Cardiol. 36: 433-437.

12. Hearse, D. J., and S. M. Humphrey. 1975. Enzyme release during myocardial anoxia: a study of metabolic protection. J. Mol. Cell. Cardiol. 7: 463-482.

13. Gebhard, M. M., H. Denhaus, K. Sakai, and P. G. Spieckermann. 1977. Energy metabolism and enzyme release. $J$. Mol. Med. 2: 271-283.

14. Maroko, P. R., and S. F. Vatner. 1977. Altered relationship between phosphokinase and infarct size with reperfusion in conscious dogs. J. Mol. Med. 2: 309-315.

15. Sobel, B. E., and W. E. Shell. 1975. Diagnostic and prognostic value of serum enzyme changes in patients with acute myocardial infarction. Prog. Cardiol. 8: 165-198.

16. Jennings, R. B., H. M. Sommers, J. P. Kaltenbach, and J. J. West. 1964. Electrolyte alterations in acute myocardial ischemic injury. Circ. Res. 14: 260-269.

17. DeLeiris, J., and D. Feuvray. 1973. Factors affecting the release of lactate dehydrogenase from isolated rat heart after calcium and magnesium free perfusion. Cardiovasc. Res. 7: 383-390.

18. Steenbergen, C., G. Deleeuw, C. Barlow, B. Change, and J. R. Williamson. 1977. Heterogeneity of the hypoxic state in perfused rat heart. Circ. Res. 41: 606-615. 